\title{
XIX. Answer to "remarks on Mr. Riddle's claim to the invention of a new method of determining the latitude
}

\section{Mr. Edward Riddle}

To cite this article: Mr. Edward Riddle (1821) XIX. Answer to "remarks on Mr. Riddle's claim to the invention of a new method of determining the latitude, Philosophical Magazine Series 1 , 58:280, 103-104, DOI: $10.1080 / 14786442108652575$

To link to this article: http://dx.doi.org/10.1080/14786442108652575

曲 Published online: 29 Jul 2009.

Submit your article to this journal $[\pi$

Џll Article views: 2

Q View related articles $\sqsubset$ 
serve effects which we cannot trace to any satisfactory cause. I an in habits of collecting facts which may, aided by the observations of others, lead at some future period to legitimate conclusions. I try all bodies of iron by means of a sensitive magnet, and find in them properties not generally understood. I find that a good magnet will equally, as by electricity or galvanism, impart polarity to needles, ly mere juxta-position. I have rendered magnetic three pieces of wire, situated in a semicircular form, opposite to the poles of a powerful magnet.-All bars standing or fixed perpendicularly (such as all iron railings in streets) are magnetic; the North pole being at the bottom, and the South at the top. The bottoms or lower parts of all common chimney-grates are North, while the tops are South poles. The iron handles of pumps are magnetic ; the furthest out-end being a North, while the end nearest to the pump is a South pole. Large weighing weights possess polarity; as also all iron hars for sale in shops. It is a curious fact, that the uppermost part or top of the iron round a carriage-wheel attracts the North end of a magnet, and is consequently a South pole, while the lower part of the same iron in contact with the ground, attracts the South end of the needle, and is therefore a North pole. Turn the same wheel round half a circle, and these poles will immediately become reversed.

I mention these few out of many experiments, in order to induce others to assist in ascertaining facts, with a view of establishing what is now wanting,-a sure Magnetic Theory. Yours, \&c. John MacDonald.

XIX. Answer to "Remarks on Mr. RIDDLE's Claim to the Invention of a new Method of determining the Latitude." By $M r$. EDWARD RiDDle.

\section{To Dr. Tilloch.}

SrR, - $\mathbf{I}_{\mathbf{N}}$ answer to the extraordinary charges of your correspondent $\gamma$, I beg leave simply to state, That in the 8 th volume of the Edinburgh Phil. Trans., which was published in 1818, and which I first saw in October of that year, General Brisbane intimated his intentiou of making a communication " On the mode of determining latitudes by the sextant most correctly by a series of observations made near noon."-That this was the whole of the announcement, and that it was unaccompanied by any hint respecting the nature of the method, or any other remark whatever.

That 


\section{Answer to Remarks on determining the Lalitude.}

That in Octoler 1818 I transmitted to you a full account of a method of finding the latitude by observations made with the sexlant near nocn, which I had practised for a considerable time previous; and that the observations in the accompanying example were made on September 24, 1817.

That in the spring of $1821 \mathrm{I}$ observed a notice in the Edinburgh Phil. Journal, that Gen. Brisbane's promised communication on this subject was just published in the Edinburgh Phil. Trans.; and in May 182l, when volume ix. part l. of the Edinburgh Phil. Trans. was received in Neweastle, I saw the paper itself for the first time. It forms article XIV. of the part.

That although it is thus impossible I could have been indebted to General B. for a method which I had previously practised for several years, and had actually published two years before I had any means of knowing what his method was, in a work in the hands of every scientific person in Europe; our methods are not only generally similar, but absolutely the same both in principle and in all their practical details.

That, whatever Gen. B. may have done, I have never seen any of the three foreign works in which your correspondent says the substance of the same method is to be found.

.That, if I were disposed to quitble, I might say that the designation of "a new method" is not'mine, as you know very well, sir, that the title of my letter in which that designation is introduced was prefixed by yourself.

That, though I am sure every thing is done at Greerwich in the best possible way, I believe I need not say that the observations made at that admirable establishment are made with other and better instruments than a sextant and an artificial horizon. And, finally, that the charge of incorrectness in an approximate formula arising from substituting the are of one second for the sine of the same arc, requires no notice.

With respect to the insinuation that I did not practise the method of fiuding the time which I stated myself to have practised, till I saw Gen. B.'s communication on the subject; - the affirmative, as the matter stands, depends on $m y$ integrity; - the negative rests not on any authority whatever. From myself, on this subject, no other reply will be expected.

\section{Your obedient servant,}

Trinity House School, Newcastle,

EDWARD Ridde. Aug. 6, 1821. 